\title{
NISSOLIA GENTRYI (LEGUMINOSAE, PAPILIONOIDEAE), A NEW SPECIES FROM SONORA AND SINALOA, MEXICO
}

\author{
Velva E. Rudd \\ Department of Biology \\ California State University, \\ Northridge, CA 91330, U.S.A. \\ Department of Botany \\ Smithsonian Institution \\ Washington, D.C. 20560, U.S.A.
}

\begin{abstract}
A new species, Nissolia gentryi, from the states of Sonora and Sinaloa, Mexico is described. It appears to be related to $N$. platycarpa Benth. from eastern México and $N$. chiapensis Rudd from the states of Oaxaca and Chiapas.
\end{abstract}

\section{RESUMEN}

Se describe Nissolia gentryi sp. $n$. de los estados mexicanos de Sonora y Sinaloa. La especie parece tener afinidad con $N$. platycarpa Benth. de la parte oriental de México y con $N$. chiapensis Rudd de los estados de Oaxaca y Chiapas.

Some years ago when a revision of the genus Nissolia was published (Rudd, 1956), I had some reservations about including collections from Sonora and Sinaloa in Nissolia platycarpa Benth., a species otherwise known from farther east in México. After further consideration I have decided to recognize the westernmost specimens as representing a new species, $N$. gentryi, named in honor of Howard Scott Gentry, intrepid botanical explorer and collector.

With the exception of $N$. fruticosa Jacq., which extends from Sinaloa, México southward to Paraguay and Argentina, the dozen or so remaining species of the genus are known from relatively limited ranges in México and bordering Arizona and Texas. The distributional success of $N$. fruticosa may be due to its somewhat woody stems and the ability to climb high on trees. The winged fruits can thus be readily disseminated by the wind. The other species are herbaceous to suffrutescent, prostrate to climbing but more limited in height, with less extensive dispersal.

In most cases the differences between species of Nissolia are subtle, enhanced by geographic separation. The two species, $N$. platycarpa and $N$. gentryi, occur on opposite sides of the Sierra Madre Occidental, and a third somewhat similar species, $N$. chiapensis (Rudd, 1975) known from Oaxaca and Chiapas, is separated from them by the transverse 
volcanic zone of central México (Fig. 1). The three species all have white-pubescent twining stems, fasciculate inflorescences, yellowish flowers $8-12 \mathrm{~mm}$ long, pubescent calyces usually beset with a few glandular setae, and fruit similarly pubescent and setose. Each species, however, exhibits characters, or combinations of characters, that differentiate it, as indicated in the following key.

1. Inflorescences (1-)2-5(-8)-flowered; flowers (8-)9-12 mm long on pedicels about 4-15 $\mathrm{mm}$ long.

2. Stems pubescent with appressed or subappressed hairs; inflorescences (1-)2$5(-8)$-flowered; flowers $9-10 \mathrm{~mm}$ long on pedicels (5-)8-10(-15) $\mathrm{mm}$ long; calyx 3-5 $\mathrm{mm}$ long with tube 2-3 $\mathrm{mm}$ long, $2 \mathrm{~mm}$ in diameter, the teeth 1-2 $\mathrm{mm}$ long; fruit crisp-pubescent and glandular-setose, (1-)2-4-seeded, constricted between the seeds and articulated, the stipe $1.5 \mathrm{~mm}$ long; leaflets elliptic, glabrous or subglabrous above, glabrous to subappressed-pubescent beneath (Tamaulipas, Nuevo León, Coahuila, San Luis Potosí, Hidalgo, Veracruz, Puebla)

N. platycarpa

2. Stems pubescent with spreading, lax, or crispate hairs; inflorescences 2-4flowered; flowers (8-)10-12 mm long on pedicels 4-7 mm long; calyx 6-8 mm long with tube 3-4 mm long, 3-3.5 mm in diameter, the teeth 2-4 mm long; fruit crisppubescent and setose, 1-seeded, not articulated, sessile; leaflets elliptic to ovate, sparsely to moderately pubescent with lax hairs above, moderately to densely pubescent beneath (Sonora, Sinaloa).

N. gentryi

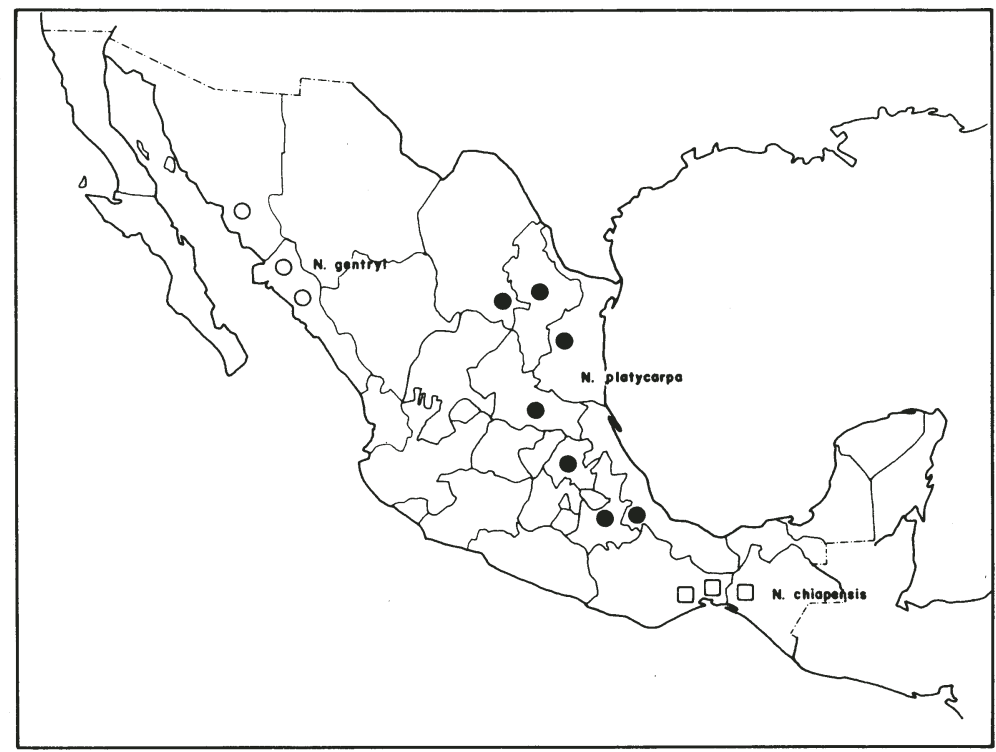

Fig. 1. Geographic distribution of Nissolia gentryi Rudd, N. platycarpa Bentham and N. chiapensis Rudd. 


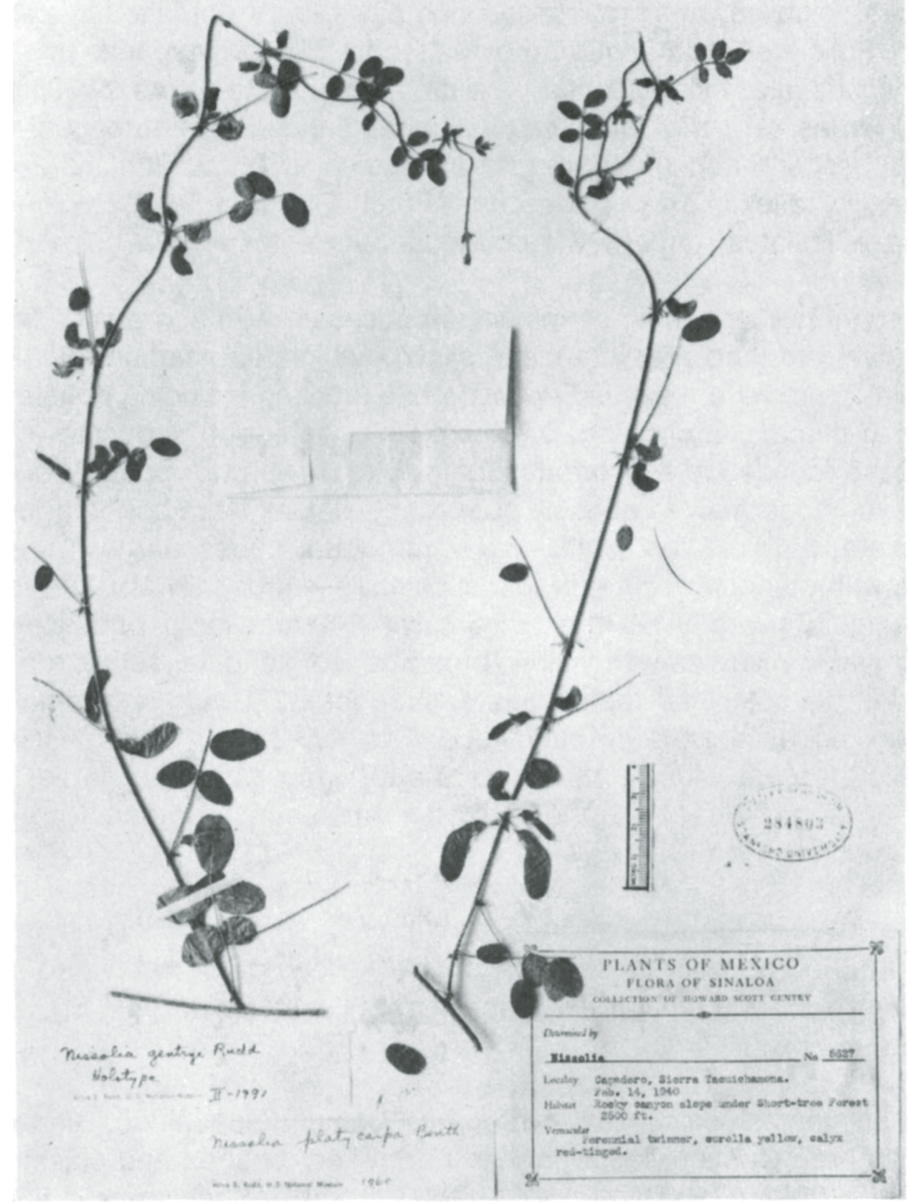

Fig. 2. Nissolia gentryi Rudd. Holotype showing flowers and fruit.

1. Inflorescences about 10-20-flowered; flowers $10 \mathrm{~mm}$ long on pedicels $1-3 \mathrm{~mm}$ long; calyx 5-6 mm long with tube $2-3 \mathrm{~mm}$ in diameter, the teeth $3-4.5 \mathrm{~mm}$ long; fruit puberulent to velutinous and setose, 3-4-seeded, lightly constricted between the seeds, articulated, the stipe $2.3 \mathrm{~mm}$ long; leaflets ovate to elliptic, puberulent above, sometimes glabrescent, the lower surface tomentulose when young, puberulent with age (Oaxaca, Chiapas) N. chiapensis 
Nissolia gentryi Rudd, sp. nov. (Fig. 2)

Suffrutices volubiles, ramis pubescentibus pilis albidis patentibus, laxis, vel crispis. Folia 5-foliolata. Foliola elliptica usque ad ovata, supra pilis laxis sparsis, subtus pilis laxis sparsis vel densis vestita. Inflorescentiae axillares, fasciculatae, fere 2-4-florae, pedicellis 4-7 mm longis. Flores $8-12 \mathrm{~mm}$ longi; calyx campanulatus, $6-8 \mathrm{~mm}$ longus, tubo $3-4 \mathrm{~mm}$ longo, patenti-pubescenti nonnumquam glanduli-setoso, dentibus ligulatis $2-4 \mathrm{~mm}$ longis; petala lutea, vexillo reflexo, extas pubescenti. Fructus totus $1.5-2.5 \mathrm{~cm}$ longus, sessilis, 1-spermus, non articulatus, pubens atque aliquandum setosus, ala apice obtusa.

Suffrutescent twining vines; stems white-pubescent with spreading, lax, or crispate hairs. Stipules ovate to lanceate, attenuate, slightly laciniate, glandular-denticulate, (2-)4$6 \mathrm{~mm}$ long, 0.5-1.2 mm wide. Leaves 5-foliolate, $3-8 \mathrm{~cm}$ long including petiole $2-4 \mathrm{~cm}$ long. Leaflets elliptic to ovate, $1-2 \mathrm{~cm}$ long, $0.7-2 \mathrm{~cm}$ wide, obtuse to subacute at apex, briefly apiculate, the base rounded to subcordate, sparsely to moderately pubescent with lax hairs to glabrous above, moderately to densely pubescent with lax hairs beneath. Inflorescences axillary, fasciculate, 2-4-flowered; pedicels 4-7 mm long, pubescent with spreading hairs and sometimes with glandular setae; bracts stipule-like but usually smaller, to $4 \mathrm{~mm}$ long; bracteoles lacking. Flowers 8-12 mm long; calyx 6-8 mm long, pubescent with white spreading hairs and sometimes with yellow, broad-based glandular setae, the tube $3-4 \mathrm{~mm}$ long, 3-3.5 mm in diameter, the teeth ligulate, subequal, $2-4 \mathrm{~mm}$ long; petals yellow, the vexillum reflexed, pubescent on the outer face. Fruit $1.5-2.5 \mathrm{~cm}$ long, sessile, 1 -seeded, not articulated, pubescent with short, lax hairs and a few glandular setae, the wing 1.5 $\mathrm{cm}$ long, $0.8-1 \mathrm{~cm}$ wide, rounded at the apex, the basal, fertile portion $1 \mathrm{~cm}$ long, $0.5 \mathrm{~cm}$ wide, usually 3-costate.

Type: México. Sinaloa, "Capadero, Sierra Tacuichamona, rocky canyon slope under Short-tree forest, $2500 \mathrm{ft}$., perennial twiner, corolla yellow, calyx red-tinged", 14 February 1940, H. S. Gentry 5627 (holotype DS; isotypes GH, M, NA, NY, POM). Specimens in flower and fruit.

Other specimens studied: México, Sonora, "Canyon Guadalupe, Sierra Chiribo, Rio Mayo: Lower Sonoran Canyon, milpa, a vine on low dry bushes and slashings, 6 March 1935, H. S. Gentry 1382 (GH, MEXU, NY, POM, UC, WIS). Specimens in flower. Sinaloa, vicinity of Culiacán, Cofradía, 29 October 1904, T. S. Brandegee s.n. (UC, US). Specimens in flower and fruit. "Cuesta de Rata Moza, moist swale at foot of oaks, $2000 \mathrm{ft}$., twining vine with yellow flowers", 19 January 1940, H. S. Gentry 5388 (DS, GH, NA, NY). Specimen in flower.

In addition, Dr. Alfonso Delgado S. suggests that the collections H. S. Gentry 14313 (MEXU) from "Cerros de Navachiste about Bahía Topolobampo", Sinaloa, and J. M. Aguilar et al. 117 (MEXU). From "9 km al E de Concordia, carr. Mazatlán-Dgo.", Sinaloa, might also be referable to $N$. gentryi. 


\section{ACKNOWLEDGMENTS}

I am indebted to Dr. Alva Day and Mr. Walter Knight for their kindness in photographing the holotype specimen of the Dudley Herbarium at the California Academy of Sciences in San Francisco, California and to Dr. Alfonso Delgado S. (at MEXU) for his helpful comments.

\section{LITERATURE CITED}

Rudd, V. E. 1956. A revision of the genus Nissolia. Contr. U. S. Natl. Herb. 32: 173-206.

Rudd, V. E. 1975. Nissolia chiapensis, a new species of Leguminosae from México. Phytologia 31: 427430. 